\title{
Intrakranial arteriedisseksjon
}
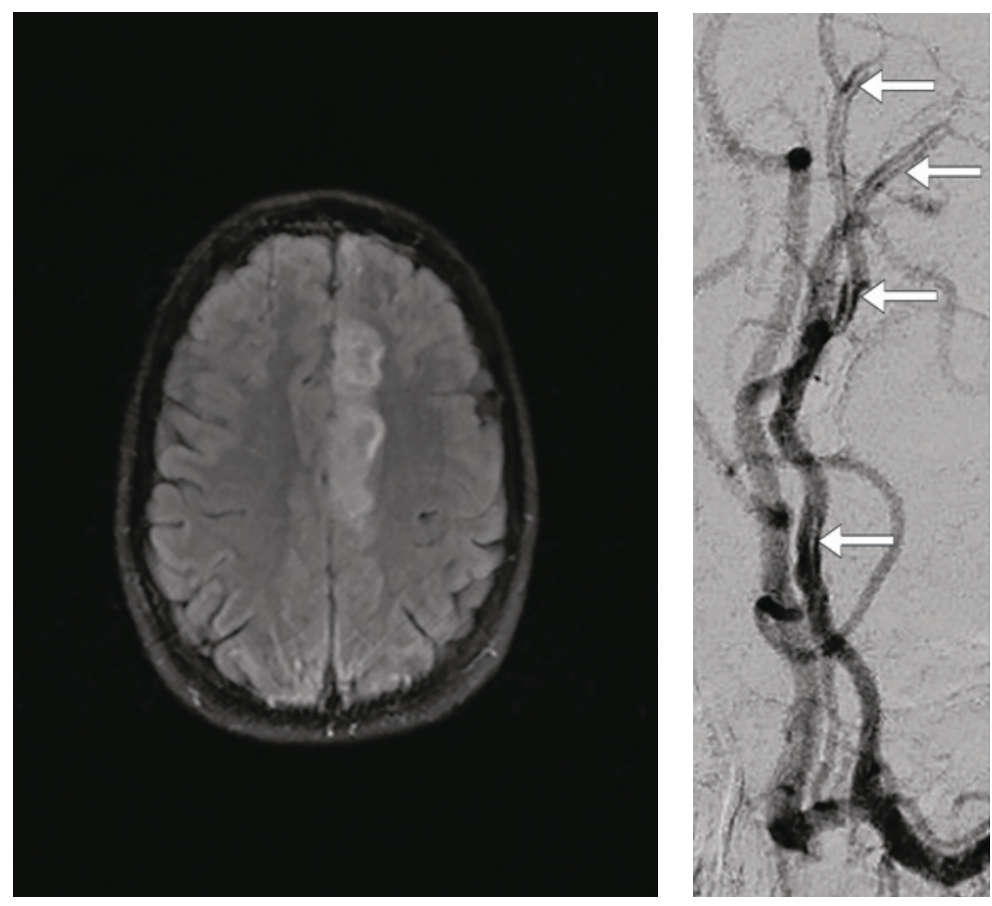

En tidligere frisk kvinne i 20-årene fikk intens hodepine etterfulgt av akutt høyresidig hemiparese og afasi under en joggetur. Hun hadde ingen vaskulære risikofaktorer og brukte ingen medisiner, bortsett fra et østrogenfritt antikonsepsjonspreparat. Hennes mor og mormor har hemiplegisk migrene.

Ved innkomst $\mathrm{i}$ akuttmottak halvannen time etter symptomdebut hadde hun vedvarende høyresidig hemiparese, dominerende $\mathrm{i}$ beinet. Akutt cerebral CT med CTangiografi viste ikke blødning eller annet patologisk. Man forventer ikke at eventuelle iskemiske forandringer vil være synlige på CT så kort tid etter ictus, men på grunn av klinisk mistanke om akutt hjerneinfarkt fikk hun trombolytisk behandling intravenøst knappe to timer etter symptomdebut.

Cerebral MR dagen etter innkomst (bildet til venstre) viste infarktforandringer i mediale deler av venstre frontallapp, svarende til forsyningsområdet til venstre a. cerebri anterior, og MR-TOF-angiografi viste noe trombosering i A2-segmentet av arterien. Pasienten gjennomgikk omfattende utredning uten at man fant noen bakenforliggende årsak til infarktet. Etter to uker ble hun undersøkt med konvensjonell cerebral angiografi, som avdekket en disseksjon i A2-segmentet av venstre a. cerebri anterior (bildet til høyre). En måned senere var hun tilbake i full jobb, da var NIHSS-skår 0 (National Institute of
Health Stoke Scale) og modified Rankin Scale (mRS) også 0 .

Fordi intrakranial arteriedisseksjon forekommer sjelden er prevalens, risikofaktorer og optimal behandling ikke systematisk undersøkt, men en relativ overhyppighet blant unge slagpasienter og i den etnisk asiatiske befolkning taler for at det er en genetisk komponent (1). Intrakranial arteriedisseksjon er hyppigere bakenforliggende årsak til hjerneinfarkter i forsyningsområdet til a. cerebri anterior enn til hjerneinfarkter $\mathrm{i}$ andre kargebeter (2) og bør derfor spesielt overveies ved cerebrale iskemiske forandringer i mediale deler av hemisfæren som forsynes av a. cerebri anterior.

Pasienten har gitt samtykke til at artikkelen blir publisert.

\section{Gerd Haga Bringeland}

gabd@helse-bergen.no

Nevrologisk avdeling

Haukeland universitetssykehus

\section{Jonas Anders Lind}

Radiologisk avdeling

Haukeland universitetssykehus

\section{Solveig B. Glad}

Nevrologisk avdeling

Haukeland universitetssykehus

\section{Utrike Waje-Andreassen}

Nevrologisk avdeling

Haukeland universitetssykehus
Gerd Haga Bringeland (f. 1987) er lege i spesialisering.

Forfatter har fylt ut ICMJE-skjemaet og oppgir ingen interessekonflikter.

Jonas Anders Lind (f. 1973) er overlege ved seksjon for nevroradiologi.

Forfatter har fylt ut ICMJE-skjemaet og oppgir ingen interessekonflikter.

Solveig B. Glad (f. 1965) er ph.d., spesialist i nevrologi og overlege ved slagenheten. Forfatter har fylt ut ICMJE-skjemaet og oppgir ingen interessekonflikter.

Ulrike Waje-Andreassen (f. 1962) er professor, spesialist i nevrologi og overlege ved slagenheten. Forfatter har fylt ut ICMJE-skjemaet og oppgir ingen interessekonflikter.

Litteratur

1. Debette S, Compter A, Labeyrie MA et al. Epidemiology, pathophysiology, diagnosis, and management of intracranial artery dissection. Lancet Neurol 2015: 14: 640-54.

2. Sato S, Toyoda K, Matsuoka $\mathrm{H}$ et al. Isolated anterior cerebral artery territory infarction: dissection as an etiological mechanism. Cerebrovasc Dis 2010; 29: 170-7.

Mottatt 11.12. 2015, første revisjon innsendt 18.3. 2016, godkjent 2.5. 2016. Redaktør: Lars Frich.

Engelsk oversettelse på www.tidsskriftet.no 